\title{
Paleomagnetism of Siluro-Devonian rocks from eastern Maine ${ }^{1}$
}

\author{
Dennis V. Kent and NeIL D. Opdyke \\ Department of Geological Sciences, Columbia University, New York, NY 10025, U.S.A. \\ and Lamont-Doherty Geological Observatory, Palisades, NY 10964, U.S.A. \\ Received March 27, 1980 \\ Revision accepted July 7, 1980
}

\begin{abstract}
A diverse suite of rocks was collected for paleomagnetic study from two formations in the Eastport area of northeastern Maine: 18 sites (103 samples) from redbeds and diabase sills of the Hersey Formation (uppermost Silurian to Lower Devonian) and 14 sites (74 samples) from lavas, redbeds, and calcareous nodules of the Eastport Formation (Lower Devonian; $\mathrm{Rb} / \mathrm{Sr}$ age 412 $\mathrm{Ma}$ ). Characteristic magnetizations based on AF and thermal demagnetization analyses give mean directions, after simple correction for bedding tilt, of $D=163.6^{\circ}, I=41.3^{\circ}, \alpha_{95}=6.3^{\circ}$, for $N=16$ sites in the Hersey, and $D=179.3^{\circ}, I=38.0^{\circ}, \alpha_{95}=9.4^{\circ}$, for $N=14$ sites in the Eastport Formation. Baked contact relations, the presence of opposite polarities, and the similarity in directions over different rock types and magnetic carriers point to an acquisition of magnetization near to the time of rock formation. The mean directions correspond to (south) paleopole positions at $19.8^{\circ} \mathrm{S}$ lat., $308.8^{\circ} \mathrm{E}$ long. $\left(\delta \mathrm{p}, \delta \mathrm{m}=4.7^{\circ}, 7.7^{\circ}\right)$ for the Hersey and $23.7^{\circ} \mathrm{S}$ lat., $293.7^{\circ} \mathrm{E}$ long. $\left(\delta \mathrm{p}, \delta \mathrm{m}=6.6^{\circ}, 11.1^{\circ}\right)$ for the Eastport Formation.

These paleopoles are removed from the Upper Silurian Bloomsburg Formation pole, but are in reasonable agreement with similar age results from central Newfoundland, suggesting that the Acadia displaced terrain encompassed these areas. Siluro-Devonian paleopoles from intrusive rocks in northeastern North America are generally widely divergent and these may not be providing an accurate record of paleomagnetic field in all cases.
\end{abstract}

On a prélevé une suite diversifiée de roches pour l'étude paléomagnétique de deux formations dans la région d'Eastport dans le nord-est du Maine: 18 sites (103 échantillons) dans les lits rouges et les filons-couches de diabase de la formation de Hersey (fin du Silurien - Dévonien inférieur) et 14 sites ( 74 échantillons) dans des laves, des lits rouges et des nodules calcareuses de la formation d'Eastport (Dévonien inférieur; âge au $\mathrm{Rb} / \mathrm{Sr}$ de $412 \mathrm{Ma}$ ). Les aimantations caractéristiques basées sur les analyses de désaimantation thermique et dans un champ alternatif donnent des directions moyennes, après correction seulement pour le pendage des formations, de $D=163,6^{\circ}$, $I=41,3^{\circ}, \alpha_{95}=6,3^{\circ}$ pour 16 sites dans la formation de Hersey et $D=179,3^{\circ}, I=38,0^{\circ}, \alpha_{95}=9,4^{\circ}$ pour 14 sites dans la formation d'Eastport. Les relations de contacts recuits, la présence de polarités inversées et la similitude dans les directions pour des types de roches et des vecteurs magnétiques différents indiquent que l'aimantation a été acquise à peu près au moment de la formation de la roche. Les directions moyennes correspondent à une position du paléopôle (sud) situé à une latitude de $19,8^{\circ} \mathrm{S}$, une longitude de $308,8^{\circ} \mathrm{E}\left(\delta \mathrm{p}, \delta \mathrm{m}=4,7^{\circ}, 7,7^{\circ}\right)$ pour la formation de Hersey et à une latitude de $23,7^{\circ} \mathrm{S}$ et une longitude de $293,7^{\circ} \mathrm{E}\left(\delta \mathrm{p}, \delta \mathrm{m}=6,6^{\circ}, 11,1^{\circ}\right)$ pour la formation d'Eastport.

Ces paléopôles sont éloignés de ceux de la formation de Bloomsburg du Silurien supérieur mais s'accordent assez bien avec les pôles d'âge semblable dans le centre de Terre-Neuve, ce qui suggère que les terrains déplacés d'Acadie comprenaient ces régions. Les paléopôles du Siluro-Dévonien des roches intrusives du nord-est de l'Amérique du Nord sont généralement très divergents et ils peuvent ne pas fournir une image précise du champ paléomagnétique dans tous les cas.

Can. J. Earth Sci., 17, 1653-1665 (1980)

[Traduit par le journal]

\section{Introduction}

Mid- to Late Devonian paleomagnetic data from North America (Schutts et al. 1976; Kent and Opdyke 1978; Irving 1979) have been interpreted as demonstrating the displaced nature of an area that includes coastal New England and part of the Canadian Maritime Provinces, which we refer to as Acadia. This has been discussed more fully in the above papers, and is supported by subsequent

\footnotetext{
${ }^{1}$ Lamont-Doherty Geological Observatory contribution \#3054.
}

paleomagnetic studies (Van der Voo et al. 1979; Kent and Opdyke 1979). In brief, Acadia is believed to have been situated some $15^{\circ}$ south of its present position with respect to Laurentia (cratonic North America) during Late Devonian to Early Carboniferous time, and then moved northward to its present position by the Late Carboniferous. Because of the lack of evidence of a closed ocean of Carboniferous age in the Northern Appalachians a transcurrent type of displacement has been hypothesized.

While the post-Devonian history of Acadia 
seems now reasonably well documented by paleomagnetic data, its earlier history is still problematical and is the focus of this study. Several tectonic models have been proposed. An early model by McKerrow and Ziegler (1972) considered this area as a promontory of the Baltic Shield which collided with Laurentia to close an intervening ocean in the mid-Devonian, resulting in the Acadian orogeny. Subsequent models considered this area as a separate subcontinent, which collided with cratonic North America in the Devonian (Scotese et al. 1979) or as part of the now dispersed continent of Armorica, which collided with North America in the Ordovician, producing the Taconic orogeny (Van der Voo 1979).

In order to test these tectonic models and to trace the origin of Acadia, paleomagnetic data are needed from older rocks. To augment this data base, we report paleomagnetic studies of SiluroDevonian rocks from the Eastport area of Maine, the same area from which previous studies of the Upper Devonian Perry Formation contributed to the evidence for the displaced nature of Acadia.

\section{Geologic Setting}

The rocks of the coastal volcanic belt of New England and New Brunswick record almost continuous marine volcanism ranging in age from Early Silurian to Early Devonian, followed by an episode of folding, faulting, and intrusion of granitic and gabbroic plutons during Middle Devonian time (Gates 1969). Numerous faults cut and disrupt the coastal volcanic belt, the major ones striking northeast to east and generally having steep dips. Deformation probably began in the Silurian and continued intermittently to post-Triassic time, although many of the major faults were active mostly in Carboniferous and (or) Triassic times (Webb 1969).

The coastal volcanic sequence reaches a maximum thickness of about $14000 \mathrm{~m}$ in the Eastport quadrangle of southeastern Maine where we have concentrated our paleomagnetic studies. Mapping of this area was originally done by Bastin and Williams (1914) and more recently by Gates (1975), from whose work the geological sketch map in Fig. 1 is drawn. The bulk of the rocks consists of a heterogeneous suite of fossiliferous marine sedimentary and volcanic rocks. They lie in a generally conformable sequence with some intertonguing, and are overlain with angular unconformity by the Upper Devonian Perry Formation. The Perry Formation, however, is also tilted, in some localities to near-vertical but typically about $20^{\circ}$, and also cut by faults. At least two phases of defor- mation are therefore indicated, the first of which resulted in the angular unconformity at the base of the Perry Formation ( mid-Devonian) and a later deformation which tilted the Perry and perhaps at the same time produced some of the faults in the area (post-Late Devonian).

Two formations were sampled for paleomagnetic study; the Hersey and Eastport Formations. The Hersey Formation is characterized by dark maroon siltstones and sandstones, intruded by tabular diabase bodies which appear conformable to bedding. The restricted fauna in the sediments consist of pelecypods, gastropods, and ostracodes, which indicate a shallow or brackish water environment. The ostracode fauna suggest that the SilurianDevonian boundary may be somewhere within the Hersey Formation (Berdan 1971).

The Eastport Formation locally overlies and in other areas is laterally equivalent to the Hersey Formation. A lower basaltic member of flows and coarse tuff is overlain by a vitrophyric member consisting of flow-banded rocks, flow breccia, and coarse lithic tuff. The formation is capped by an upper basaltic member. Intercalated in this volcanic sequence are several sections of gray and maroon conglomerate, shale, siltstone, and oolitic limestone. The sedimentary rocks with their characteristic structures (cross-bedding, ripple marks, and mud cracks) and restricted fauna suggest deposition in very shallow water and the basalt may be largely terrestrial, although pillows occur in some areas. The stratigraphic position of the Eastport Formation above the Hersey and the affinity of its ostracode genera to somewhat similar forms in Europe suggest a Gedinnian (i.e., Early Devonian) age (Berdan 1971; Berry and Boucot 1970). Bottino and Fullagar (1966) assigned a $\mathrm{Rb}-\mathrm{Sr}$ whole-rock age of $412 \pm 5 \mathrm{Ma}$ to a devitrified vitrophyre in the Eastport Formation. An angular unconformity separates the Eastport Formation from the overlying fluvial red clastic rocks of the Perry Formation.

A total of 103 oriented drill core samples were obtained from 18 sites in the Hersey Formation, nine sites in the redbeds and nine sites in diabase sills (Fig. 1). Bedding tilts are generally from $20^{\circ}$ to $40^{\circ}$ to the northeast. Oriented drill core samples (74 in number) were also taken from 14 sites distributed over various rock types in the Eastport Formation. Half of the sites are in lavas, four sites are in redbeds, two sites are in calcareous nodules within gray shallow-water siltstones, and one site is in a diabase sill. Bedding attitudes range from nearly horizontal to dips of $60^{\circ}$, again mostly to the northeast. Some of the redbeds sampled in both the 

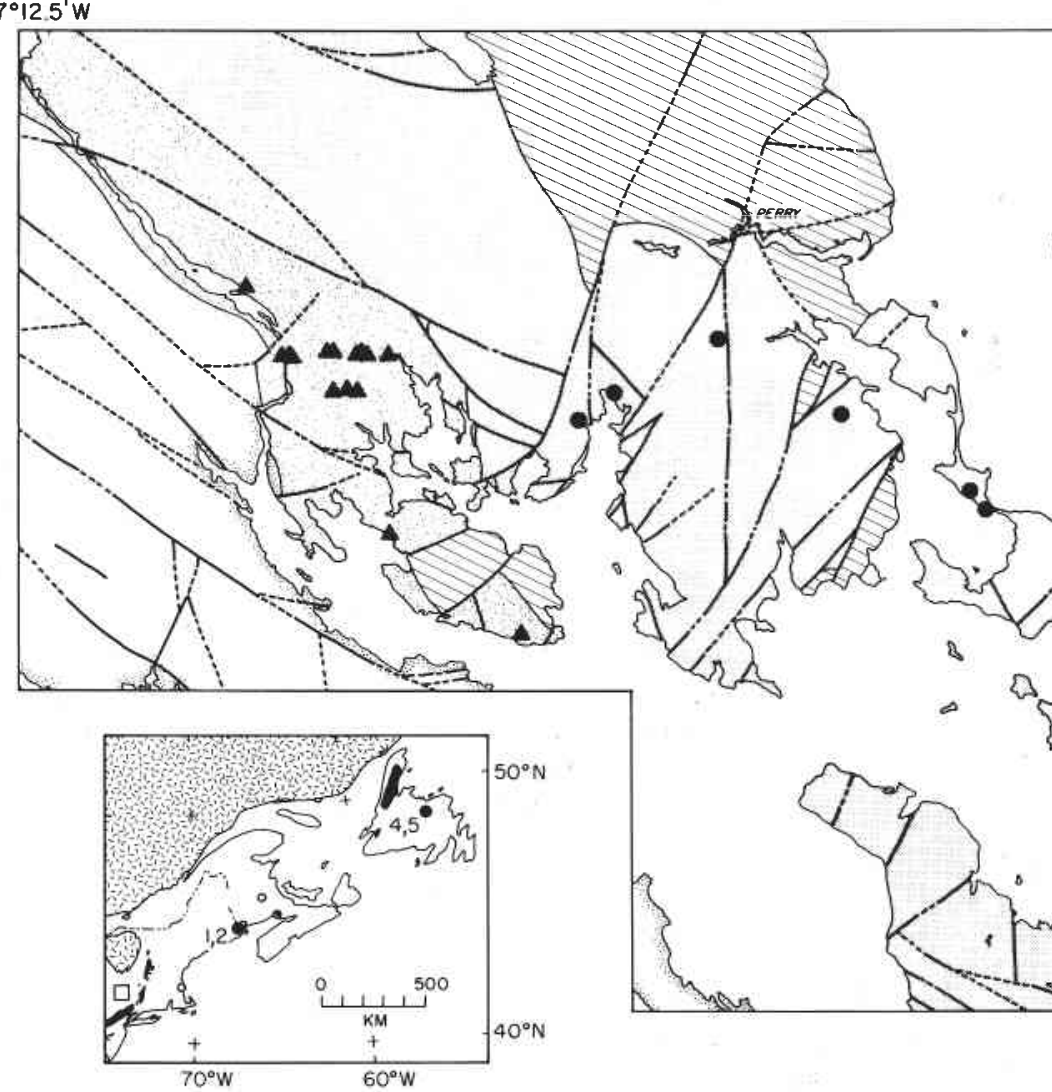

FIG. 1. Geological sketch map of part of Eastport, Maine area showing outcrop distribution of Perry Formation (diagonal pattern), Eastport Formation (regular dot pattern), and Hersey Formation (irregular dot pattern). Locations of sampling sites in Eastport Formation and in Hersey Formation are shown, respectively, by filled circles and filled triangles. The heavy lines denote fault traces; broken where inferred. Inset: Regional map showing Precambrian Shield (stippled pattern) and isolated exposures of Grenville basement (darkened areas), which together indicate minimum geographic extent of Laurentia. The Acadia displaced terrain encompasses some part of the New England and the Canadian Maritime provinces to the east and south. Small open circles are selected sampling localities of Upper Devonian and Lower Carboniferous rocks, which give paleopoles interpreted as evidence for displacement of Acadia; open square is sampling locality of Middle to Upper Devonian Catskill redbeds, which give a paleopole representative of Laurentia (see Kent and Opdyke 1978). Solid circles are selected sampling localities of Siluro-Devonian rocks, the adjacent numbers keyed to Table 3 with 1,2 the present study of the Hersey and Eastport Formations.

Hersey and Eastport Formations have been baked by sills or lavas, providing a contact test for stability of magnetization.

\section{Magnetic Measurements}

The directions of natural remanent magnetization (NRM) for the igneous and sedimentary rocks of the two formations are plotted without correction for bedding tilt in Fig. 2. The NRM directions show no marked concentration near to the present-day geomagnetic field direction at the sampling locality, but tend to lie with some scatter around a southerly direction on the lower hemisphere of the projection. The lack of an obvious grouping around the present-day field direction im- plies the presence of a stable component of ancient origin. Progressive demagnetization techniques were applied to all samples to isolate and identify the various components that may be present.

\section{Demagnetization Analyses}

Vector diagrams (Zijderveld 1967) illustrating the demagnetization behavior of the NRM of representative samples from the Hersey Formation are shown in Fig. 3. The initial demagnetization steps in almost all cases show the removal of a northerly, steeply dipping down component that generally conforms to the present-day in-situ magnetic field direction, and which can be considered of recent origin. In the sills, this component is removed progressively with higher alternating fields (AF) to re- 


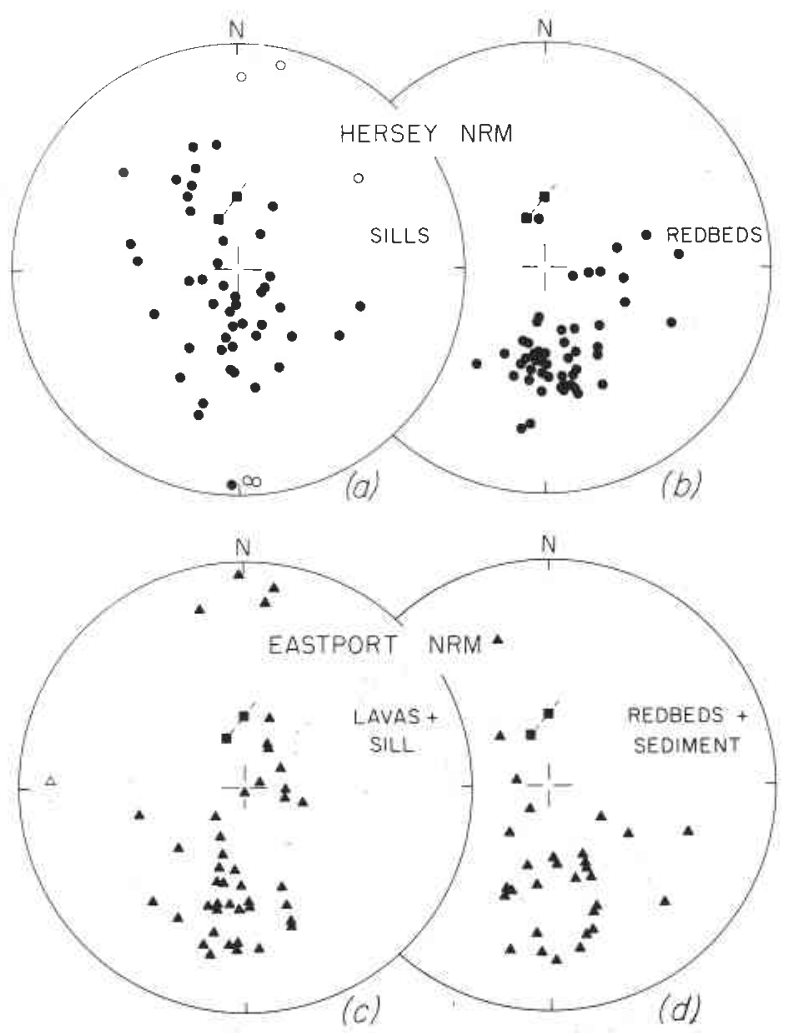

FIG. 2. Sample NRM directions in Hersey Formation (a, b) and Eastport Formation (c, d), plotted without tilt correction. Filled (open) symbols on lower (upper) hemisphere of equalarea projections. Filled square is present geomagnetic field direction and filled square primed is expected dipole field direction for locality.

veal a southerly magnetization, which decays linearly to the origin and essentially disappears by 1000 Oe (Fig. 3a). More erratic behavior is sometimes observed in the lowest coercivity range of demagnetization (Fig. $3 b$ ) and probably reflects magnetizations acquired since the rocks were sampled. Nevertheless, the same higher coercivity component could be isolated in most of the sill samples and on this basis is considered their characteristic magnetization. Judging from the moderate coercivities, the magnetization of the sill rocks can be attributed to magnetite or a titanomagnetite.

The present-day field component in the Hersey redbeds is readily removed by either thermal demagnetization to a few hundred degrees Celsius (Fig. 3c) or AF demagnetization (Fig. $3 d$ ) to again reveal a characteristic southerly magnetization, which has a linear trajectory to the origin with further thermal demagnetization. The magnetizations persist to temperatures of around $670^{\circ} \mathrm{C}$, which correspond to blocking temperatures of hematite. At one redbed site, however, this component trajectory by-passes the origin to an inflection at about $660^{\circ} \mathrm{C}$, after which an essentially antiparallel component shows a decay to the origin (Fig. 3e). Opposite polarities have been detected in individual redbed samples elsewhere, and have been interpreted as reflecting different stages of chemical remanence, perhaps in addition to an original detrital remanence over a period of time that encompassed geomagnetic polarity reversals (e.g., Roy and Park 1974). In our case, however, the proximity of this redbed site to a diabase sill suggests local heating effects may be responsible, as will be discussed below with other evidence of baked contacts.

A more diverse suite of rocks was sampled in the Eastport Formation, but the demagnetization characteristics are generally similar to those described for the Hersey redbeds and sills. The magnetizations can be mostly attributed to a combination of a present-day field component and a southerly component that is revealed at higher levels of demagnetization. However, there are several interesting features worthy of note.

Vector demagnetization diagrams typical of the lavas are shown in Fig. 4. Although most of the magnetization can be removed by 900 Oe, there typically remains a fraction with higher coercivities and with blocking temperatures ranging to approximately $670^{\circ} \mathrm{C}$ (Fig. $4 a$ ). The moderate coercivities suggest that magnetite is the dominant magnetic remanence carrier in the lavas, which is also indicated by the concentration of blocking temperatures around the Curie point of this mineral (Fig. 4b). However, the persistence of the remanence to high blocking temperatures indicates a contribution from hematite. It is possible that the hematite formed a long time after the lavas were emplaced, but the virtually identical magnetization directions for the two inferred magnetic phases suggest a common time of origin.

In several of the lavas, the final direction of magnetization is essentially antiparallel to the directions at the other sites (Fig. $4 c$ ) and evidently records a magnetic field of opposite polarity. This antiparallel magnetization again persists to high blocking temperatures, and is evidently also carried in part by hematite, although most of the magnetization has blocking temperatures appropriate to magnetite. The fact that the two inferred magnetic phases can record different polarity states in different lavas is evidence for a time of origin of both magnetic phases that is closely related to the initial cooling of the lavas, for example, by deuteric processes, rather than some pervasive chemical or 


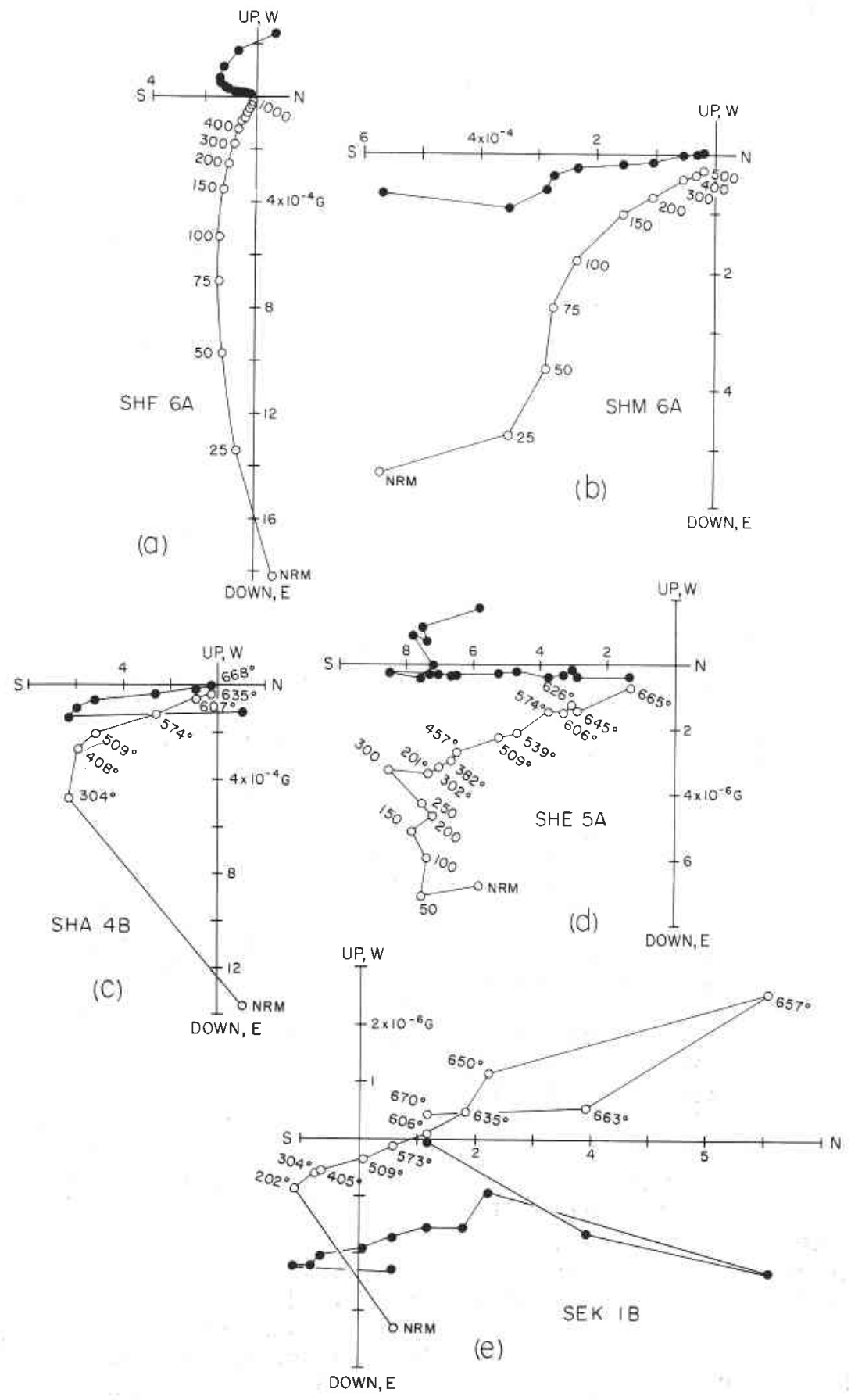

FIG. 3. Vector end-point diagrams of NRM demagnetization of selected Hersey Formation samples (a, b are diabase sills; $c$, $\mathrm{d}$, e are redbeds). Open circles are end-points projected on $\mathrm{N}-\mathrm{S}$ vertical plane, filled circles on horizontal plane. Numbers adjacent to circles are AF peak oersteds and those with degrees, Celcius temperature used in demagnetization. Magnetization units on axes are labelled.

thermal event much later in the history of the rocks. ing associated with the emplacement of the overThe southerly magnetization component that is lying lavas that have predominantly southerly dipresent between $460^{\circ}$ and $570^{\circ} \mathrm{C}$ in the sample rections of magnetization. shown in Fig. $4 c$ most likely reflects a mild reheat- Representative vector demagnetization dia- 


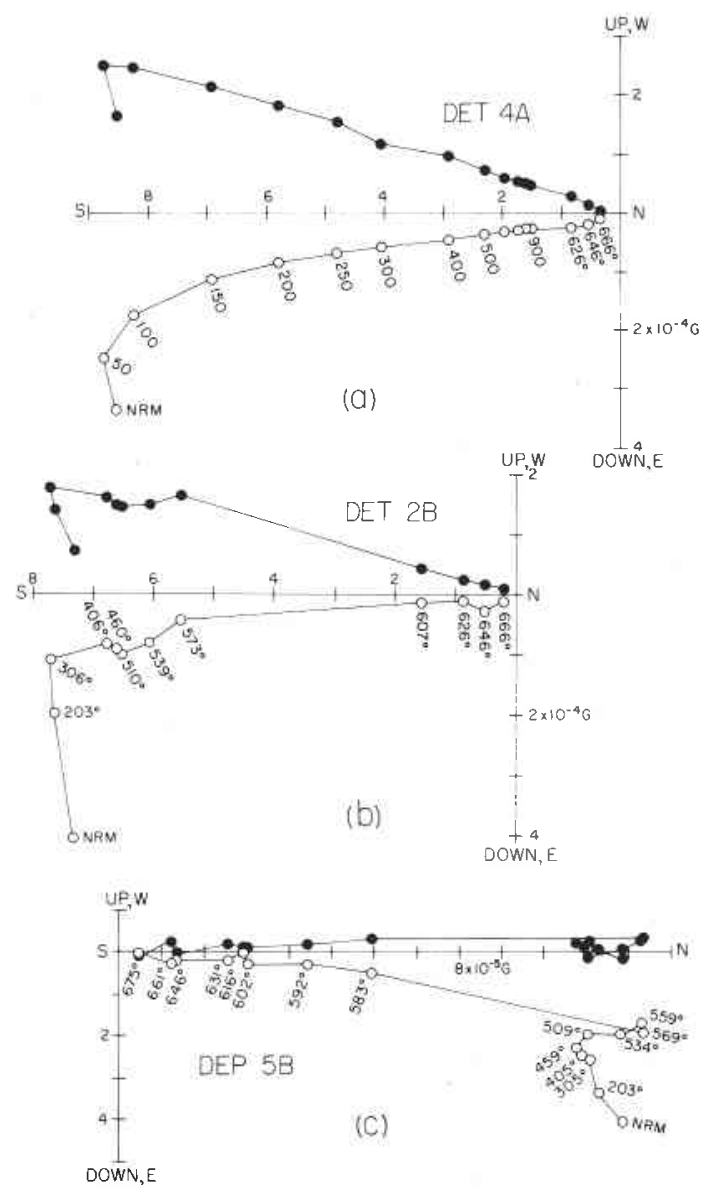

FIG. 4. Vector diagram of NRM demagnetization of lava samples from Eastport Formation. Description same as for Fig. 3.

grams of sedimentary rocks sampled in the Eastport Formation are shown in Fig. 5. As could be expected the NRM intensities are generally much lower than in the lavas, but nevertheless the components of magnetization are similar. The final magnetizations are invariably southerly, with moderate coercivities and maximum blocking temperatures appropriate for magnetite in the calcareous nodules (Figs. $5 a, b$ ) and persisting to temperatures of at least $666^{\circ} \mathrm{C}$, typical of hematitic rocks, in the redbeds (Fig. 5c).

\section{Baked Contacts}

Several redbed sites are either in close proximity to a diabase sill in the Hersey Formation or directly overlain by lavas in the Eastport Formation and consequently provide a field test for stability of magnetization. In the Hersey Formation, sites SEL and SEM are from a diabase sill, which was intruded into redbeds sampled within $1 \mathrm{~m}$ of the con- tact at site SEN; the site mean characteristic directions of these sites are statistically the same (Table 1). Site SEK was sampled in redbeds a few metres away from the sill, and apparently has been only partly affected by the emplacement of the sill. A direction similar to that of the sill and baked contact is present in the intermediate blocking temperature range, but an essentially antiparallel direction can be resolved in the high temperature range of demagnetization (e.g., Fig. 3e). The agreement between the direction of magnetization of the sill and contact rock is evidence that both retain a stable magnetization acquired when the igneous intrusion cooled, while the antiparallel, high blocking temperature component in the redbed site (SEK) at a greater distance from the sill can be interpreted as a pre-existing magnetization that has been partly overprinted as a result of the emplacement of the sill. The elevated remanent intensity of the contact rock (SEN; $2.9 \times 10^{-5} \mathrm{G}$ ) compared to site SEK $\left(0.6 \times 10^{-5} \mathrm{G}\right)$ supports this conclusion.

In the Eastport Formation, one of the lavas (site DET) clearly overlies and has apparently baked a redbed unit (site DES). The directions of magnetization of the two sites are virtually identical (Table 2 ), and the remanent intensity of the baked redbed is more than one order of magnitude greater than unbaked redbeds in the Eastport Formation. These relationships are consistent with the retention of a stable remanence in both lava and baked contact from the time the igneous unit cooled.

Baked and unbaked sedimentary rocks can also be distinguished on the basis of magnetochemical changes, as reflected in changes in magnetic susceptibility that result during thermal demagnetization (Fig. 6). For both redbed and calcareous nodule samples, the room temperature susceptibilities stay the same or decrease slightly after heating to temperatures of about $500^{\circ} \mathrm{C}$, and then increase markedly to values that are typically an order of magnitude greater than initially by $650^{\circ} \mathrm{C}$. The susceptibility of baked redbed samples, on the other hand, increases by only a factor of 2 or 3 , and virtually all of the increase occurs above about $625^{\circ} \mathrm{C}$. Interestingly, the initial values of susceptibility for the baked contact rocks are invariably greater than for the unbaked sediments, by approximately the amount the unbaked sediments increase during laboratory heating. The differences in initial magnetic properties between baked and unbaked sediments, and the fact that heating the unbaked samples in the laboratory produces some of the magnetic properties associated with the baked contact rocks, are further evidence that 


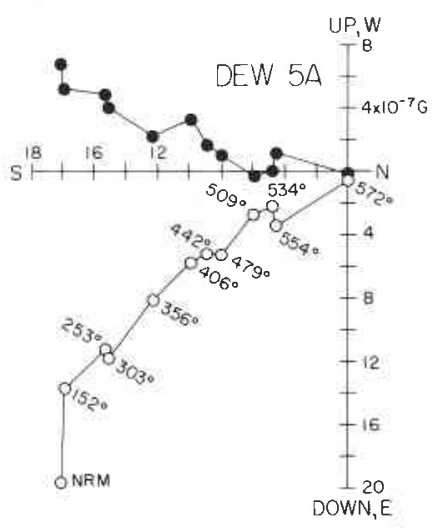

(a)

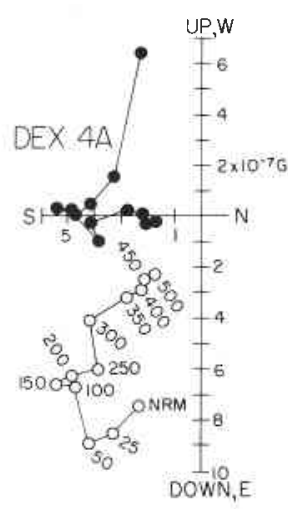

(b)

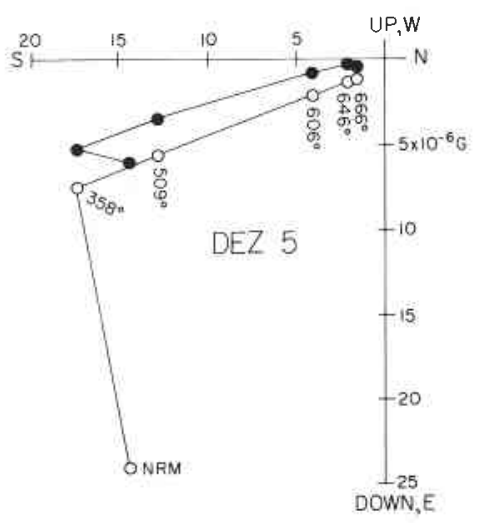

(C)

FIG. 5. Vector diagrams of NRM demagnetization of calcareous nodules $(a, b)$ and redbed (c) from Eastport Formation.

TABLE 1. Site mean characteristic directions of the Hersey Formation

\begin{tabular}{|c|c|c|c|c|c|c|c|c|}
\hline \multirow[b]{2}{*}{ Site } & \multirow[b]{2}{*}{ Rs } & \multirow[b]{2}{*}{ Treat. } & \multicolumn{2}{|c|}{ Before T.C. } & \multicolumn{2}{|c|}{ After T.C. } & \multirow[b]{2}{*}{$k$} & \multirow[b]{2}{*}{$\alpha_{95}\left(^{(}\right)$} \\
\hline & & & Decl. $\left({ }^{\circ}\right)$ & Incl. $\left({ }^{\circ}\right)$ & Decl. $\left({ }^{\circ}\right)$ & Incl. $\left({ }^{\circ}\right)$ & & \\
\hline \multicolumn{9}{|c|}{ Sills } \\
\hline SHB & $4 / 4$ & $\mathrm{AF}$ & $(311.5$ & 68.5 & - & - & 184 & $6.8)$ \\
\hline SHC & $3 / 6$ & $\mathrm{AF}$ & 196.7 & 58.2 & 158.4 & 58.1 & 9 & 43.3 \\
\hline SHF & $6 / 6$ & $\mathrm{AF}$ & 191.2 & 46.0 & 167.9 & 60.1 & 40 & 10.7 \\
\hline SHI & $0 / 6$ & $\mathrm{AF}, \mathrm{Th}$ & - & - & - & 0.1 & (unstable) & 10.7 \\
\hline SHM & $5 / 6$ & $\mathrm{AF}$ & 172.0 & 19.7 & 156.3 & 35.2 & 39 & 12.4 \\
\hline SEA & $4 / 6$ & $\mathrm{AF}$ & 194.1 & 43.6 & 174.3 & 54.5 & 62 & 11.7 \\
\hline SEC & $5 / 6$ & $\mathrm{AF}$ & 167.3 & 50.4 & 142.3 & 51.4 & 45 & 11.5 \\
\hline SEL & $3 / 4$ & $\mathrm{AF}$ & 187.8 & 34.2 & 163.7 & 44.4 & 46 & 18.3 \\
\hline SEM & $6 / 6$ & AF & 198.3 & 31.6 & 170.0 & 48.4 & 143 & 5.6 \\
\hline \multicolumn{9}{|c|}{ Redbeds } \\
\hline SHA & $5 / 5$ & Th & 177.5 & 22.7 & 168.2 & 20.7 & 64 & 9.6 \\
\hline SHD & $3 / 6$ & Th & 168.3 & 33.2 & 152.0 & 31.9 & 1078 & 3.8 \\
\hline SHE & $4 / 5$ & Th & 178.9 & 24.5 & 167.8 & 36.5 & 566 & 3.8 \\
\hline SHG & $7 / 7$ & Th & 176.5 & 35.7 & 155.3 & 33.5 & 105 & 5.9 \\
\hline SHH & $6 / 6$ & Th & 178.9 & 36.1 & 150.6 & 36.0 & 197 & 4.7 \\
\hline SHK & $5 / 6$ & Th & 185.4 & 24.2 & 175.4 & 37.1 & 99 & 7.7 \\
\hline SHL & $2 / 6$ & Th & 183.5 & 19.4 & 168.2 & 40.6 & - & - \\
\hline SEK & $3 / 6$ & Th & 8.3 & -11.0 & 356.9 & -23.9 & 11 & 39.0 \\
\hline SEN & $6 / 6$ & Th & 190.0 & 25.8 & 168.0 & 42.2 & 111 & 6.4 \\
\hline
\end{tabular}

Formation mean $16 / 18$ sites $(82 / 103$ samples, omitting sites SHB and SHI)

Before T.C. decl. $=183.2^{\circ}$ incl. $=32.6^{\circ} \quad k=30 \quad \alpha_{95}=6.8^{\circ}$

pole position: lat. $=27.3^{\circ} \mathrm{S}$ long. $=289.4^{\circ} \mathrm{E} \quad \delta \mathrm{p}=4.3^{\circ} \quad \delta \mathrm{m}=7.7^{\circ}$
After T.C.
decl. $=163.6^{\circ}$ incl. $=41.3^{\circ} \quad k=36 \quad \alpha_{95}=6.3^{\circ}$

pole position: lat. $=19.8^{\circ} \mathrm{S}$ long. $=308.8^{\circ} \mathrm{E} \quad \delta \mathrm{p}=4.7^{\circ} \quad \delta \mathrm{m}=7.7^{\circ}$

NOTEs: $\mathbf{R s}=$ proportion of collected samples (sites) used to calculate mean direction; Treat. = demagnetization technique used AF, alternating field and Th, thermal; $k=$ estimate of precision parameter; $\alpha_{95}=$ radius of circle of $95 \%$ confidence; $\delta \mathrm{p}$ and $\delta \mathrm{m}$
are the semi-axes of oval of $95 \%$ confidence.

these Eastport Formation rocks retain many of their original magnetic characteristics from the time of their formation.

\section{Results}

The site mean characteristic directions for the
Hersey and Eastport Formations are shown in Fig. 7 and in Tables 1 and 2 . The magnetization of one diabase sill (site SHI) in the Hersey is dominated by unstable components and no coherent direction can be isolated. Another site (SHB) was actually in a small dike cutting a diabase sill (site SHC) and gives 
TABLE 2. Site mean characteristic directions of the Eastport Formation

\begin{tabular}{|c|c|c|c|c|c|c|c|c|}
\hline \multirow[b]{2}{*}{ Site } & \multirow[b]{2}{*}{ Rs } & \multirow[b]{2}{*}{ Treat. } & \multicolumn{2}{|c|}{ Before T.C. } & \multicolumn{2}{|c|}{ After T.C. } & \multirow[b]{2}{*}{$k$} & \multirow[b]{2}{*}{$\alpha_{95}\left(^{\circ}\right)$} \\
\hline & & & $\operatorname{Decl} .\left(^{\circ}\right)$ & Incl. $\left({ }^{\circ}\right)$ & $\operatorname{Decl} .\left(^{\circ}\right)$ & Incl. $\left(^{\circ}\right)$ & & \\
\hline \multicolumn{9}{|c|}{ Lavas and sill } \\
\hline DEA & $5 / 5$ & Th & 203.6 & 23.7 & 204.5 & 28.3 & 67 & 9.4 \\
\hline DEB & $6 / 6$ & Th & 191.5 & 32.0 & 192.3 & 36.9 & 96 & 6.8 \\
\hline $\mathrm{DEC}$ & $5 / 5$ & Th & 186.1 & 29.0 & 186.5 & 34.0 & 20 & 17.6 \\
\hline DEP & $4 / 6$ & Th & 354.0 & -3.6 & 350.6 & -20.7 & 18 & 22.5 \\
\hline DER & $4 / 6$ & $\mathrm{Th}$ & 1.6 & 26.6 & 8.8 & -12.3 & 78 & 10.4 \\
\hline $\mathrm{DET}$ & $5 / 5$ & $\mathrm{AF}$ & 192.9 & 12.4 & 158.7 & 43.7 & 115 & 7.1 \\
\hline DEV & $5 / 5$ & Th & 189.1 & 14.4 & 154.1 & 41.2 & 50 & 10.9 \\
\hline DEY* & $6 / 6$ & Th & 168.6 & 24.9 & 180.5 & 45.2 & 141 & 5.6 \\
\hline \multicolumn{9}{|c|}{ Redbeds and sediments } \\
\hline DEQ & $4 / 4$ & Th & 209.4 & 29.8 & 195.8 & 49.0 & 72 & 10.8 \\
\hline DES & $5 / 5$ & Th & 194.2 & 13.0 & 158.8 & 45.1 & 120 & 7.0 \\
\hline DEU & $3 / 4$ & Th & 179.3 & 22.3 & 140.6 & 35.1 & 131 & 10.8 \\
\hline DEZ & $6 / 6$ & Th & 174.2 & 20.9 & 173.6 & 49.0 & 118 & 6.1 \\
\hline DEW & $5 / 5$ & Th & 189.1 & 17.9 & 199.6 & 31.4 & 41 & 12.0 \\
\hline DEX & $6 / 6$ & Th & 183.7 & 22.4 & 196.2 & 37.5 & 20 & 17.4 \\
\hline
\end{tabular}

Formation mean $14 / 14$ sites (69/74 samples)

Before T.C. decl. $=186.8^{\circ}$ incl. $=17.7^{\circ} \quad k=20 \quad \alpha_{95}=9.0^{\circ}$

pole position: lat. $=35.7^{\circ} \mathrm{S}$ long. $=284.7^{\circ} \mathrm{E} \quad \delta \mathrm{p}=4.8^{\circ} \quad \delta \mathrm{m}=9.3^{\circ}$

After T.C. $\quad$ decl. $=179.3^{\circ}$ incl. $=38.0^{\circ} \quad k=19 \quad \alpha_{95}=9.4^{\circ}$

pole position: lat. $=23.7^{\circ} \mathrm{S}$ long. $=293.7^{\circ} \mathrm{E} \quad \delta \mathrm{p}=6.6^{\circ} \delta \mathrm{m}=11.1^{\circ}$

\begin{abstract}
NOTEs: $\mathbf{R s}=$ proportion of collected samples (sites) used to calculate mean direction; Treat. = demagnetization technique used $\mathrm{AF}$, alternating field and Th, thermal; $k=$ estimate of precision parameter; $\alpha_{95}$ is radius of circle of $95 \%$ confidence; $\delta \mathrm{p}$ and $\delta \mathrm{m}$ are the semi-axes of oval of $95 \%$ confidence. "DEY is in sill.
\end{abstract}

an anomalous direction (Fig. 7a). This result may represent a much younger magnetization than in the other Hersey sites and will not be considered further in the absence of supporting evidence.

The remaining Hersey sites $(N=16)$ give a formation mean direction of $D=183.2^{\circ}, I=31.6^{\circ}, k=$ $30, \alpha_{95}=6.8^{\circ}$. The sense of this direction corresponds to a reversed polarity, and the direction of one site (SEK), which apparently records the opposite (normal) polarity, was inverted for the purpose of calculation. Correction for bedding tilt gives a marginal improvement in grouping $(k=36)$ with a mean direction of $D=163.6^{\circ}, I=41.3^{\circ}, \alpha_{95}$ $=6.3^{\circ}$ (Fig. $7 b$ ).

The characteristic site mean directions $(N=14)$ in the Eastport Formation give a formation mean of $D=186.8^{\circ}, I=17.7^{\circ}, k=20, \alpha_{95}=9.0^{\circ}$, which becomes $D=179.3^{\circ}, I=38.0^{\circ}, k=19, \alpha_{95}=9.4^{\circ}$ after correction for bedding tilt (Fig. $7 c, d$ ). Two sites in lavas (DEP, DER) have essentially opposite directions to the other sites, and these were again inverted for calculating the formation mean directions. There is virtually no difference in grouping with tilt correction.

The lack of significant change in the grouping of site mean direction in both formations after bedding tilt correction can be attributed at least in part to the generally broad, open structures with uniform bedding attitudes over large areas of outcrop (see geologic map of Gates (1975)). Additional factors may include the possibility that the strata have been tilted more than once (as discussed earlier) and since the area is cut by numerous faults, various fault-bounded-blocks may have rotated with respect to each other. For either case, a simple rotation about the present bedding strikes will not in general restore the strata or hence their magnetizations, to their original attitudes. The inclination component of a remanent vector will not be affected, but an error may be introduced in the tiltcorrected declination component. Indeed we find that the mean inclinations for the Hersey and the Eastport Formations are essentially the same whereas the mean declinations for the two formations differ significantly.

We note further that there is an azimuthal smearing of the Eastport site mean directions (Fig. $7 d)$, precisely the pattern that can be expected to result from small net rotations about local vertical axes, although the same pattern is not present in the Hersey data. This difference between the two formations can be attributed to the relative distribution of sampling sites. The Hersey sites are concentrated within a single block (Fig. 1) so that any 


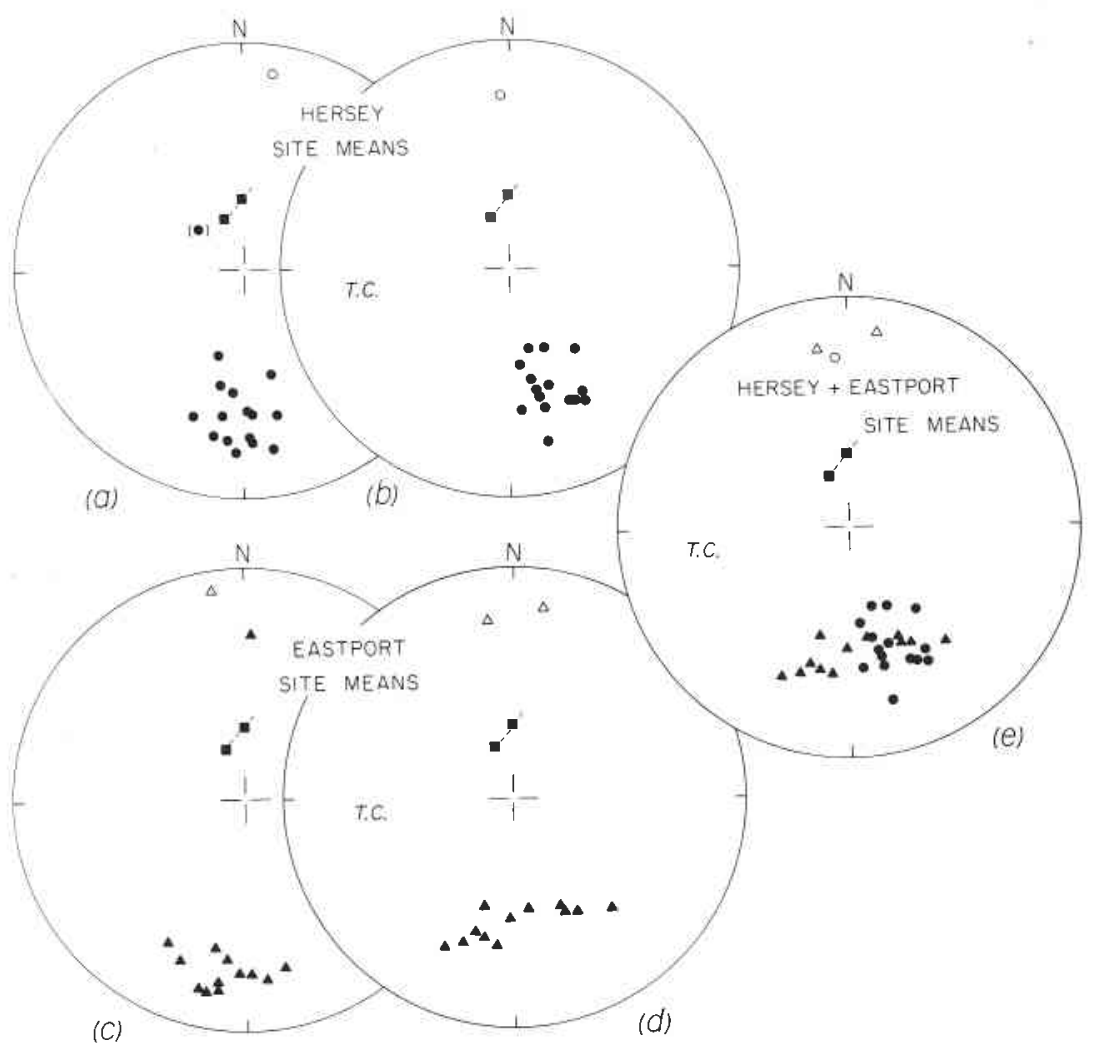

FIG. 7. Characteristic site mean directions, before and after (T.C.) tilt correction, for the Hersey (a, b) and Eastport (c, d) Formations and after tilt correction for the formations combined (e). Filled (open) symbols on lower (upper) hemisphere of equal-area projections. Filled square is present-day geomagnetic field direction and primed square is expected dipole field direction for locality. Direction in parentheses in (a) is for site SHB.

boniferous pole positions with respect to cratonic North America (Laurentia). A large scatter in these paleopoles is evident and for some it is not even clear whether they are north or south poles, since they are so far removed from known younger APW paths. All the results except for the Clam Bank Group (Black 1964; pole 6) are based on extensive demagnetization analyses, reducing the likelihood of contributions from unstable magnetizations as a cause for the scatter.

It has been suggested that the large difference in directions sometimes found in the same or nearly contemporaneous rock units represents an interval of rapid apparent polar wander (Roy et al. 1979). However, it is noteworthy that similar evidence is yet to be found in rocks from Laurentia. For example, demagnetization studies now show that the abberrant steep NRM directions in the Devonian Onondaga Limestone of New York (Graham 1956) are satisfactorily explained as the resultant of a present-day field direction combined with a characteristic component with a shallow and southerly direction (Kent 1979). While the scat- tered and generally divergent distribution of Siluro-Devonian paleopoles from Acadia can be considered to be consistent with the displaced nature of much of this region with respect to Laurentia, the tectonic movements implied by these data taken at face value seem rather excessive and highly erratic.

Despite the apparent incoherence in this set of data as a whole, some systematic relationships appear to be present. In particular, we note that poles 1, 2, 4, and 5 (Fig. 8) form a grouping near to the mean Late Devonian paleopole position for Acadia. These four paleopoles include our results from the Eastport and Hersey Formations (1 and 2), and the Botwood Group rhyolites and sandstones from central Newfoundland (4 and 5) (Lapointe 1979). The rock units from which these paleomagnetic poles were obtained are layered and structural corrections for tilting can be applied. (The pole from the Clam Bank Group redbeds (Black 1964) is in the vicinity of this grouping, but since it is based on minimal demagnetization and sampling, discussion of this early result is deferred 
magnetizations represent a sum of two or more different directions that could not be fully resolved. Roy et al. (1979) recognized this possibility in their study and showed that opposite polarities are often carried over a very narrow range of blocking temperatures. This observation is commensurate with the long cooling times expected for plutons, and we consider it quite likely that different directions may have sufficiently overlapping blocking temperatures as to be not fully resolvable, thereby leaving a resultant or multivectorial direction unrelated to any paleomagnetic dipole field. Some of the magnetic components identified by Roy et al. (1979) represent only a few percent of the NRM, which places a further experimental constraint to adequate resolution of possible multicomponent magnetizations and which may contribute to the large ovals of confidence around some of the poles (e.g., B and C on Table 3).

It is quite possible that none of the suggested mechanisms, nor even some combination of them is adequate to account for all the apparently anomalous paleomagnetic directions in these intrusions and although we think the evidence suggests otherwise, anomalous geomagnetic field behavior may even be involved. Nevertheless, pending further work on this problem, we believe that there are at present sufficient grounds to suspect that these intrusions are not providing accurate information of the direction of a paleomagnetic dipole field near to the time of the emplacement. In this regard it is interesting that of the six Ordovician poles summarized by Piper (1979) as being anomalous, far removed from all other Paleozoic studies in England, and for which an anomalous geomagnetic field has been hypothesized, four were also from intrusions, although two were reported from volcanic rocks.

\section{Discussion}

Averaging poles $1,2,4$, and 5 gives a mean Siluro-Devonian (south) paleopole for Acadia at lat. $=20.6^{\circ} \mathrm{S}$, long. $=300.4^{\circ} \mathrm{E}\left(\mathrm{A}_{95}=10.5^{\circ}\right)$ (Fig. 8 ). To be sure, even these four poles have considerable scatter, which may reflect in part some rotations about local axes in these moderately deformed rocks. Nevertheless this mean pole is removed from the Upper Silurian Bloomsburg Formation pole of Laurentia and is consistent with the other paleomagnetic evidence that Acadia is a displaced terrain. The paleolatitutde difference with Laurentia using the Bloomsburg pole places Acadia about $11^{\circ}$ south of its present position. This compares with the better defined paleolatitude differ- ence of 15 to $20^{\circ}$ later in the Devonian (Kent and Opdyke 1978; Van der Voo et al. 1979). In view of the scatter in the Acadia Siluro-Devonian poles and the few contemporaneous paleopoles from Laurentia available for comparison, we suggest that the estimate of paleolatitude difference for these two time periods may not be significantly different. This means that Acadia maintained about the same, more southerly position with respect to Laurentia throughout the Devonian, and consequently, we do not find any convincing paleomagnetic evidence for substantial relative movement between Acadia and Laurentia to associate with the mid-Devonian Acadian orogeny of the Northern Appalachians. If the Acadian orogeny represents a collisional event, as has been suggested by some (e.g., McKerrow and Ziegler 1972), some continent or tectonic plate other than Acadia was apparently involved. In this regard, we point out that British Siluro-Devonian paleopoles, which fall in equatorial latitudes (Briden et al. 1973) are not consistent with contemporaneous paleopoles from either Acadia or Laurentia when plotted on a conventional reconstruction of the circum-North Atlantic continents; there is, however, good agreement in British and Acadia paleopoles of later Devonian age. The significance of these observations with respect to the tectonic history of the region will be discussed elsewhere.

We also point out that the inferred coherence of poles 1, 2, 4, and 5 implies that Acadia existed as a coherent block that extended from coastal Maine (poles 1,2 ) to the Botwood zone of central Newfoundland (poles 4, 5; Lapointe 1979) in the Siluro-Devonian. If this geographic extent for Acadia is substantiated by further paleomagnetic work, the possible location of the zone of transcurrent motion that brought Acadia to its present position in the Carboniferous (Kent and Opdyke 1979) must lie to the northwest of these areas. Geologic features that might be related to the hypothesized Carboniferous transcurrent motion in Newfoundland may be some of the great northeast-trending faults in the western part of the island, like the Cabot Fault, whereas in New England and New Brunswick, the Clinton-Newbury and Norembega Fault systems may be possible candidates. Further constraint of the site or zone of the proposed large $(\sim 1500 \mathrm{~km})$ Carboniferous displacement in the Northern Appalachians will require additional paleomagnetic studies of rock units distributed over the region. The location of this megashear has important implications to the understanding of the earlier tectonic history, especially with regard to 
the nature of the association of mid-Devonian orogenesis with the Acadia displaced terrain.

\section{Acknowledgments}

We wish to thank R. A. Schweickert and W. Snyder for critical readings of the manuscript, Doris Lafferty for capable laboratory work, and Carolyn Kent for field assistance. This work was N supported by the National Science Foundation, Earth Sciences, under grant EAR 75-18955.

Bastin, E. S., and Williams, H. S. 1914. Eastport Folio, Maine. United States Geological Survey, Folio 192.

Berdan, J. M. 1971. Silurian to Early Devonian Ostracodes of European aspect from the Eastport Quadrangle, Maine (Abstr.). Geological Society of America, Abstracts with Programs, 3(1), p. 18.

Berry, W. B. N., and Boucot, A. J. 1970. Correlation of the North American Silurian rocks. Geological Society of America, Special Paper 102.

BLACK, R. F. 1964. Paleomagnetic support of the Theory of Rotation of the Island of Newfoundland. Nature, 202, p. 945-948.

Bottino, M. L., and Fullager, P. D. 1966. Whole-rock rubidium-strontium age of the Silurian-Devonian boundary in northeastern North America. Geological Society of O America Bulletin, 77, pp. 1167-1176.

Briden, J. C., Morris, W. A., and Piper, J. D. A., 1973. $\Rightarrow$ Paleomagnetic studies in the British Caledonides. VI. ReTional and global implications. Geophysical Journal of Royal of Astronomical Society, 34, pp. 107-134.

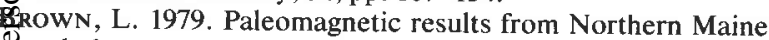
¿and the western limit of "Avalon" in the mid-Paleozoic. бGeophysical Research Letters, 6, pp. 821-824.

GATES, O. 1969. Lower Silurian - Lower Devonian volcanic rocks of New England coast and New Brunswick. American Association of Petroleum Geologists, Memoir 12, pp. 484-503.

1975. Geologic map and cross-sections of the Eastport Quadrangle, Maine. Maine Geological Survey, GM-3.

Graham, J. W. 1956. Paleomagnetism and magnetostriction. Journal of Geophysical Research, 61, pp. 735-739.

Irving, E. 1979. Paleopoles and paleolatitudes of North American and speculations about displaced terrains. Canadian Journal of Earth Sciences, 16, pp. 669-694.

IRVING, E., and OPDYKE, N. D. 1965. The paleomagnetism of the Bloomsburg Red Beds and its possible application to the tectonic history of the Appalachians. Geophysical Journal of the Royal Astronomical Society, 9, pp. 153-166.

KENT, D. V. 1979. Paleomagnetism of the Devonian Onondaga Limestone revisited. Journal of Geophysical Research, 84, pp. 3576-3588.

Kent, D. V., and Opdyke, N. D. 1978. Paleomagnetism of the Devonian Catskill Red Beds: Evidence for motion of coastal New England-Canadian Maritime region relative to cratonic North America. Journal of Geophysical Research, 83, pp. 4441-4450.
1979. The Early Carboniferous paleomagnetic field for North America and its bearing on tectonics of the northern Appalachians. Earth and Planetary Science Letters, 44, pp. 365-372.

KNowles, R. R., and Opdyke, N. D. 1968. Paleomagnetic results from the Mauch Chunk Formation: A test of the origin of curvature in the folded Appalachians of Pennsylvania. Journal of Geophysical Research, 73, pp. 6515-6526.

Kopacz, M. A., and Noltimier, H. C. 1976. The Cool Pole and the Kitaning Reversal (Abstr.). EOS, 57, p. 238.

LAPOINTE, P. L. 1979. Paleomagnetism and orogenic history of the Botwood Group and Mount Peyton batholith, Central Mobile Belt, Newfoundland. Canadian Journal of Earth Sciences, 16, pp. 866-876.

McKerrow, W. S., and Ziegler, A. M. 1972. Paleozoic oceans. Nature (Physical Sciences), 240, pp. 92-94.

Piper, J. F. A. 1979. Aspects of Caledonian paleomagnetism and their tectonic implications. Earth and Planetary Science Letters, 44, pp. 176-192.

ROY, J. L., and PARK, J. K. 1974. The magnetization process of certain red-beds: vector analysis of chemical and thermal results. Canadian Journal of Earth Sciences, 11, pp. 437-471.

Roy, J. L., Anderson, P., and LAPointe, P. L. 1979. Paleomagnetic results from three rock units of New Brunswick and their bearing on the Lower Paleozoic tectonics of North America. Canadian Journal of Earth Sciences, 16, pp. 1210-1227.

Roy, J. L., OPdyke, N. D., and IRving, E. 1967. Further paleomagnetic results from the Bloomsburg Formation. Journal of Geophysical Research, 72, pp. 5075-5086.

Schutts, L. D., Brecher, A., Hurl. ey, P. M., Montgomery, C. W., and Krueger, H. W. 1976. A case study of the time and nature of paleomagnetic resetting in a mafic complex in New England. Canadian Journal of Earth Sciences, 13, pp. 898-907.

Scotese, C. R., Bamback, R. K., Barton, C., Van der Voo, R., and ZIEGLER, A. M. 1979. Paleozoic base maps. Journal of Geology, 87, pp. 217-277.

ScotT, G. R. 1979. Paleomagnetic studies of the Early Carboniferous St. Joe Limestone, Arkansas. Journal of Geophysical Research, 84, pp. 6277-6285.

VAN DER Voo, R. 1979. Paleozoic assembly of Pangea; A new plate tectonic model for the Taconic, Caledonian, and Hercynian orogenies (Abstr.). EOS, 60, p. 241.

VAN DER VOO, R. and French, R. B. 1974. Apparent polar wandering for the Atlantic-bordering continents: Late Carboniferous to Eocene. Earth-Science Reviews, 10, pp. 99-119.

Van der Voo, R., French, A. N., and French, R. B. 1979. A paleomagnetic pole position from the folded Upper Devonian Catskill redbeds, and its tectonic implications. Geology, 7, pp. 345-348.

WEBв, G. W. 1969. Paleozoic wrench faults in Canadian Appalachians. In North Atlantic-Geology and continental drift, a symposium. Edited by Marshall Kay. American Association of Petroleum Geologists, Memoir 12, pp. 754-788.

ZiJdervelD, J. D. A. 1967. A.C. demagnetization of rocks: analysis of results. In Methods in paleomagnetism. Edited by D. W. Collinson, K. M. Creer, and S. K. Runcorn. Elsevier, New York, NY, pp. 254-286. 